\title{
Confocal fluorescence microscopy: a powerful tool in the study of Chagas' disease
}

\author{
Microscopia confocal de fluorescência: uma ferramenta \\ poderosa no estudo da doença de Chagas
}

\section{Renato Arruda Mortara ${ }^{1}$, Solange da Silva ${ }^{1}$ and Noemi Nosomi Taniwaki ${ }^{1,2}$}

\begin{abstract}
Confocal scanning fluorescence microscopy has become widely used in cell biology and pathology. In conjunction with monoclonal antibodies it may turn out to be a powerful diagnostic tool that also enables detailed studies of tissue forms of Trypanosoma cruzi.
\end{abstract}

Key-words: Trypanosoma cruzi. Chagas' disease. Confocal microscopy.

Resumo A microscopia confocal por varredura a laser vem se tornando extremamente útil na biologia celular e patologia. Com o uso de anticorpos monoclonais, pode ser uma poderosa ferramenta de diagnóstico assim como para estudos detalhados das diferentes formas do Trypanosoma cruzi em vários tecidos infectados.

Palavras-chaves: Trypanosoma cruzi. Doença de Chagas. Microscopia confocal.

Confocal fluorescence microscopy has become a powerful tool that has enabled a tremendous improvement in morphology and cell biology studies ${ }^{35}$. Its potential application in the studies of Chagas' disease has recently been demonstrated by several publications using both in vitro samples ${ }^{126}$ and also parasitized tissues from infected animals ${ }^{7}$ or even chagasic patients ${ }^{4}$.

The fundamental property of confocal systems that allow optical sectioning through the sample associated with image digitization are the basis of the potential of this technique. Very informative images regarding the state of parasite differentiation as well as a structural relationship with the host cell tissue in particular in the myocardium can be obtained by a combination of immunostaining with stage-specific monoclonal antibodies ${ }^{1}$ and DNA probes such as DAPI (4',6'-diamino-2-phenylindole, dilactate) that intensely label the parasites' nuclei and kinetoplasts. Also, most confocal systems allow simultaneous transmitted image acquisition that in combination with either phase contrast or Nomarski differential interference contrast (DIC) can also aid the unequivocal identification of Trypanosoma cruzi amastigote as well as trypomastigote forms within the myocardial fibers.

With very simple procedures that are routinely used in pathology laboratories, paraffinembedded specimens can be retrospectively examined ${ }^{4}$ using standard immunofluorescence preparations. Deparaffinized $5-10 \mu \mathrm{m}$ thick sections are incubated with a primary antibody

1. Disciplina de Parasitologia, Departamento de Microbiologia, Imunologia e Parasitologia, Escola Paulista de Medicina, Universidade Federal de São Paulo, São Paulo, SP, Brasil. 2. Seção de Microscopia Eletrônica, Instituto Adolfo Lutz, São Paulo, SP. Financial Support: FAPESP, CNPq and CAPES.

Address to: Prof. Renato A. Mortara. Disciplina de Parasitologia/DMIP/EPM/UNIFESP. R. Botucatu 862, 6o andar, 04023-062 São Paulo, SP, Brasil

Tel: 55 11 570-8306; Fax: 55 11 571-1095

E-mail: renato.dmip@epm.br

Recebido para publicação em 10/11/99. 
(that can be a specific monoclonal antibody), rinsed, and visualized by a fluorescenceconjugated secondary antibody in combination with DAPI staining. Slides are imaged directly in the confocal microscope that may be coupled with image processing and documentation accessories that can directly provide output of publicationstandard print-outs.
A

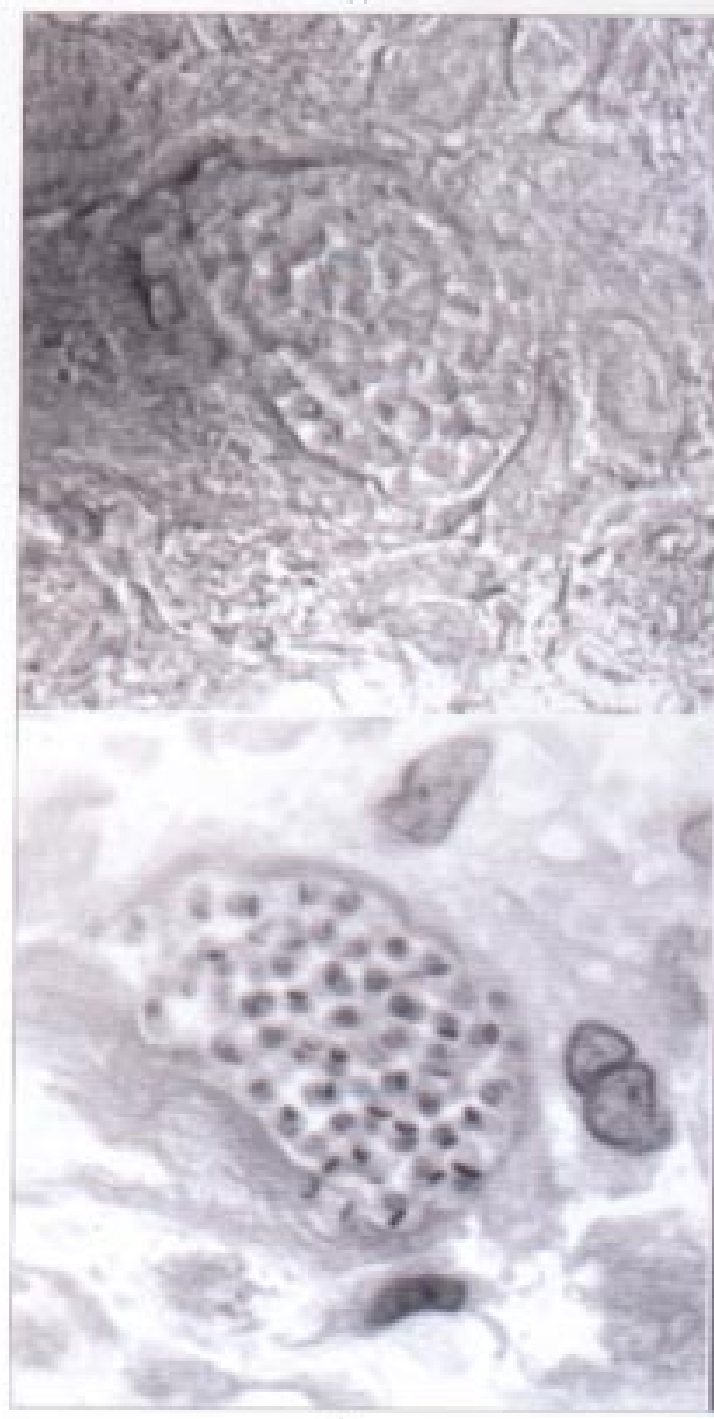

C
B

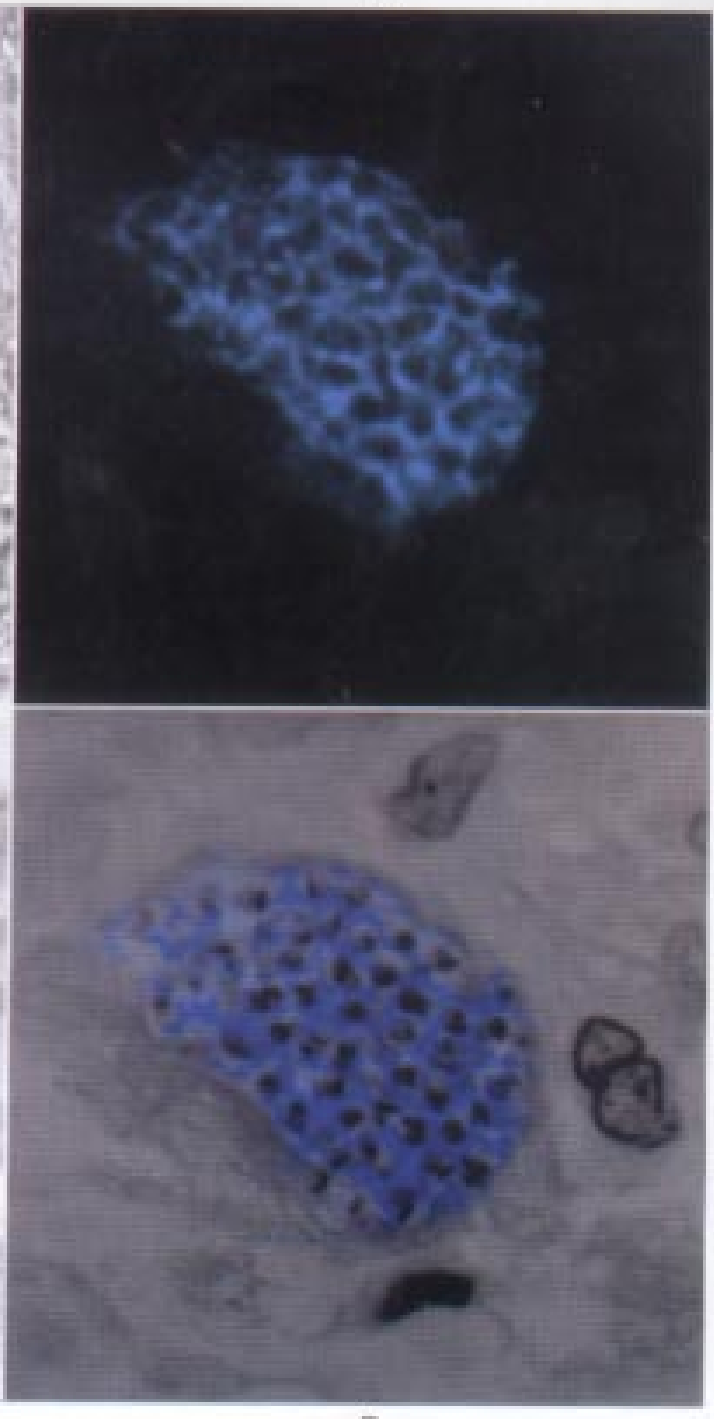

D

Figure 1 - Confocal imaging of myocardial tissue from Chagasic patient: A: Nomarski or differential interference contrast image of amastigote nest amongst cardiac myofibers. B: Confocal fluorescence image (single optical section) of same field labeled with 4D9, a monoclonal antibody that is specific for Trypanosoma cruzi amastigotes'. C: DNA labeling with $D A P I$ of same field where parasites' kinetoplasts and nuclei can be visualized with an inverted gray color table. D: overlay of immunofluorescence staining in blue on top of DAPI labeling. Magnification bar $(A)$ in $\mu m$. 


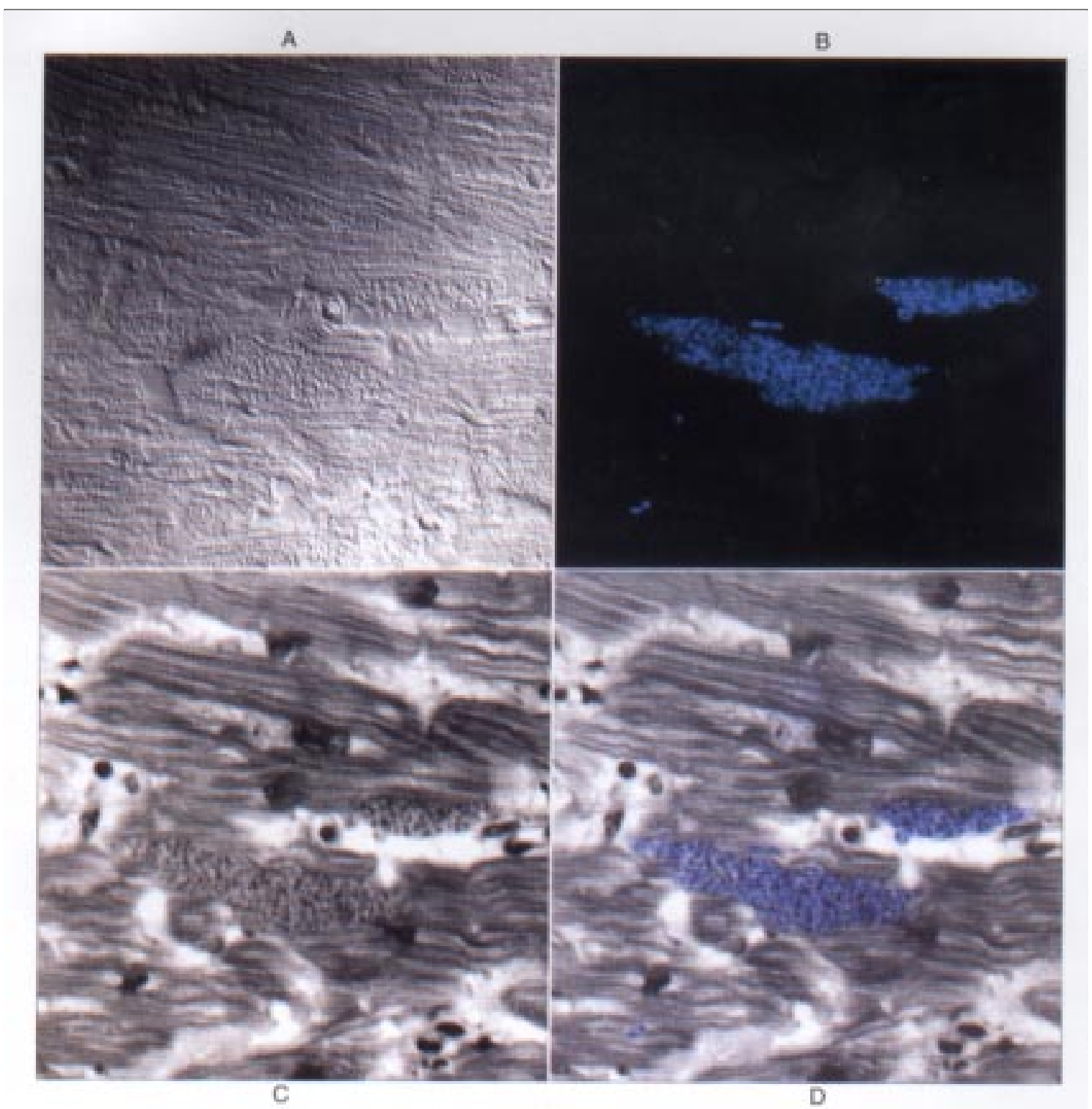

Figure 2 - Confocal imaging of myocardial tissue from chagasic patient: A: Nomarski or differential interference contrast

\section{REFERENCES}

1. Barros HC, Verbisck NV, Silva S, Araguth MF, Mortara RA. Distribution of epitopes of Trypanosoma cruzi amastigotes during the intracellular life cycle within mammalian cells. Journal of Euk. Microbiology 46:332-344, 1997.
2. De Souza W, Ulisses de Carvalho TM, Melo ET, Coimbra ES, Rosestolato CT, Ferreira SR, Vieira M. The use of confocal laser scanning microscopy to analyze the process of parasitic protozoon-host cell interaction. Brazilian Journal of Medical and Biological Research 31:1459-1470, 1998. 
3. Lichtman JW. Confocal Microscopy. Science American 271:30-35, 1994.

4. Mortara RA, Silva S, Patrício FR, Higuchi ML, Lopes ER, Gabbai AA, Carnevale P, Rocha A, Ferreira MS, Souza $\mathrm{MM}$ et al. Imaging Trypanosoma cruzi within tissues from chagasic patients using confocal microscopy with monoclonal antibodies. Parasitology Research 85:345393, 1999.

5. Paddock SW. Confocal images to go? Curr. Biology 4:857-868, 1994.
6. Procópio DO, Silva S, Cunningham CC, Mortara RA. Trypanosoma cruzi: Effect of protein kinase inhibitors and cytoskeletal protein organization and expression on host cell invasion by amastigotes and metacyclic trypomastigotes. Experimental Parasitology 90:1-13, 1998.

7. Zhang J, Andrade ZA, Yu ZX, Andrade SG, Takeda K, Sadirgursky M, Ferrans VJ. Apoptosis in a canine model of acute chagasic myocarditis. Journal Mol. Cell. Cardiology 31:581-596, 1999. 